\title{
The seafloor geomorphology of the Windmill Islands, Wilkes Land, East Antarctica: evidence of Law Dome ice margin dynamics
}

\author{
Carson $^{1}$, C.J., Post ${ }^{1}$, A.L., Smith ${ }^{1}$, J., Walker ${ }^{2}$, G., Waring ${ }^{2}$, P., Bartley ${ }^{3}$, R., and Raymond ${ }^{3}$, B. \\ ${ }^{1}$ Geoscience Australia, GPO Box 378, Canberra, ACT, 2601, AUSTRALIA \\ ${ }^{2}$ Royal Australian Navy, Balls Head Rd, Waverton, NSW, 2060, AUSTRALIA \\ ${ }^{3}$ Australian Antarctic Division, Channel Hwy, Kingston, TAS, 7050, AUSTRALIA
}

\begin{abstract}
A high-resolution multibeam sonar dataset covering an area of ca. $33 \mathrm{~km} 2$ was collected in the vicinity of the Windmill Islands $\left(67^{\circ} \mathrm{S}, 110^{\circ} \mathrm{E}\right)$, Wilkes Land, East Antarctica. The new data permit visualisation of the near-shore seafloor morphology in unprecedented detail, providing invaluable insight into the ice-sheet history of the region. A range of geomorphic features are evident, including prominent parallel northwest-trending linear fault sets affecting Mesoproterozoic metamorphic basement, which appear to control the regional coastal physiography. The fault systems probably formed during fragmentation of eastern Gondwana during the Mesozoic. Networks of sub-glacial meltwater channels, preserved on bedrock platforms and ridges, indicate grounding of a thick ice sheet over the continental shelf during previous glaciations. West-trending subtle glacial lineations and streamlined landforms record evidence of the westward expansion of the grounded Law Dome ice sheet margin, probably during the late Pleistocene. The direction of these features coincides with glacial striae on onshore crystalline bedrock outcrops. Perhaps the most striking glacial geomorphological features are sets of arcuate ridges confined mostly within glacially excavated U-shaped troughs formed by erosion of the northwest-trending bedrock fault sets. These ridge sets are interpreted as push moraines or grounding zone features, formed during episodic retreat of highly channelised, topographically-controlled ice-streams following ice surging of the Law Dome margin. This event was possibly triggered in response to local environmental forcing during the mid-late Holocene. Minor post-glacial marine sedimentation is preserved in several small $(\leq 1 \mathrm{~km} 2)$ isolated basins with shallow seaward sills.
\end{abstract}

